DOI: https://doi.org/10.47405/mjssh.v6i9.977

\begin{tabular}{|c|c|}
\hline 4.581 & Malaysian Journal of Social Sciences and Humanities (MJSSH) \\
\hline $\begin{array}{l}\text { Malaysian Journal of } \\
\text { Social cciences and }\end{array}$ & Volume 6, Issue 9, September 2021 \\
\hline (MJ-SSH) & e-ISSN : 2504-8562 \\
\hline & $\begin{array}{l}\text { Journal home page: } \\
\text { www.msocialsciences.com }\end{array}$ \\
\hline
\end{tabular}

\title{
The Use of Multimodal Text in Enhancing Students' Reading Habit
}

\author{
Nur Athirah Jamil' ${ }^{1}$ Azlina Abdul Aziz ${ }^{1}$ \\ 1 Faculty of Education, Universiti Kebangsaan Malaysia (UKM) \\ Correspondence: Nur Athirah Jamil (p102222@siswa.ukm.edu.my)
}

\begin{abstract}
Reading habit is a fundamental skill that is necessary for every student's life. However, Malaysia is far from a culture of reading. Therefore, to step forward to a world that enjoys reading, everyone needs to spread good reading habits as soon as possible. Thus, this conceptual paper provides a literature review that is relevant to students' reading habits by using multimodal text. Additionally, it explores reading habits, the importance of reading, multimodal text as instructional material, and the advantages of using multimodal text to improve students' reading habits. By identifying some advantages of using multimodal text in improving students' reading habits, such as making the learning environment more interesting and productive, encouraging more on reading habits and motivate students to read texts with passion. Thus, teachers should be encouraged to develop their own multimodal text to be used in the ESL classroom.
\end{abstract}

Keywords: reading habit, multimodal text, ESL classroom, students reading habit

\section{Introduction}

As the world expands globally, so does the language. English language learning and teaching is becoming increasingly important in many growing countries such as Japan, Canada and France, where English is taught as a foreign language (Kubota \& McKay, 2009). Aware of the language's importance in Malaysia and globally, the Malaysian government was officially introduced the Common European Framework of Reference (CEFR) through the Malaysian Education Blueprint 2013-2025. When it comes in learning the foreign language, learners also need to master for types of skills which are listening, speaking, reading and writing. Besides, reading is one of the most crucial skills for learners to gain when learning a new language (Maharsi et al., 2019).

Reading is not an easy skill to be acquired as it is regarded to be the key to academic and life success, and it is a skill that must be mastered; nevertheless, the process of learning to read is different for each individual; some may love and find it joyful, while others may find it a tough and unpleasant habit (Khairuddin, 2013). He also added that understanding learners' interest in reading English texts and the reasons that lead to high or low interest in reading can help parents, teachers, and society respond more effectively to learners' reading demands, thereby increasing their readability. Krashen (1993) also claims that reading helps learners to develop a decent writing style, a broad vocabulary, advanced grammar, and outstanding spelling skills.

As a result, abundant reading material will be beneficial for learners to meet one of the goals in the Malaysian Education Blueprint (2013-2025), which is to generate students who are at least bilingual in 
these two languages: Malay and English (Ministry of Education, 2013). To achieve this, the Malaysian government has declared that an English textbook from the United Kingdom has been imported to teach the newly established KSSM curriculum, which is compatible with the Common European Framework of Reference for Languages (CEFR). This is part of the Ministry of Education's initiative to ensure that learners will reach the competency levels that are in line with international expectations (Abdul Aziz et al., 2019).

However, by using overseas sources to enhance learners reading habits, some difficulty has occurred. Learners have difficulty understanding and relating to the content that is different from their real-life situation (Johari \& Abdul Aziz, 2019). Learners become demotivated to continue the reading as they did not fully understand what they read as the foreign textbook is written in native English. Therefore, supporting material will be helpful for learners to enhance their reading skills and cultivate their reading habits. An authentic material such as multimodal text created by teachers can assist learners better in connecting with the Malaysian environment and surroundings. It can also attract learners to read when using multimodal material as they combine visuals, hypertext, and graphic design features with textual text in various forms (Serafini, 2011). In this conceptual paper, the researcher wants to address the following research question, what are the advantages of using multimodal text in enhancing learners' reading habits?

\section{Literature Review}

\section{Reading Habit}

Reading habit can be defined as the expression of likeness in reading for each individual, which means every individual have different reading types and preferences (Sangkaeo 1999). Edeole and Adejoke (2016) claimed that the development of the reading habit of every individual should start from an early stage of life for every student through the home, i.e. parents, to the school environment as the poor reading habit has great consequences on the academic performance of every student. There have been numerous attempts to improve learners reading habits in Malaysia done by teachers. Researchers and educators have highly recommended that good reading habits should start early and that a favourable reading environment should be created to stimulate lifelong reading (Berk, 2009; Ormrod, 2006; Pandian, 2000). Students rarely choose to read for pleasure. For them, reading is a part of studying or homework.

According to Abidin et al. (2011) in their study "The Reading Habits of Malaysian Chinese University Students", students tend to learn by looking at their role model. Hence, parents are the most influential people in their life. Parents who value reading and reading themselves will promote a reading habit at home as students learn by modelling (Abidin et al., 2011). Pandian (2000) added that factors related to the background, home and school of students have an impact on their reading habits. Hence by providing a variety of topics for reading and a conducive place to read, such as a mini-library at home, reading habits can be increased among students. Moreover, learners' reading habits can be increased by providing a variety of reading materials such as books, magazines, newspapers, graphic novels, comic books, fiction or non-fiction texts and many more (Priajana, 2013). In order to compete in the global marketplaces of the future, young generations, particularly students, need to develop good reading habits.

\section{Importance of Reading}

Reading is known as one of the most crucial academic responsibilities that learners face. When the learners can instil a good reading habit, it will help learners acquire useful knowledge. Reading is also known to have a big influence that can significantly contribute to learners' successful job rate, career development, and ability to respond to change wherever they are when working (Kirsch \& Guthrie, 1984). In their study, Bashir and Mattoo (2012) agreed that a good reading habit can help learners where they that reading is an important skill where learners can use their good reading habits as a powerful weapon to help them succeed in life. Palani (2012) added that reading is important as it can 
mould people's personalities, aids in the development of right-thinking skills, and generates new ideas. The entire educational process is also intertwined with reading skills as it is a vital component for effective learning in the ESL classroom.

It is important to be able to acquire good reading habits and skills. Many studies that associate with the importance of reading has been made on teenagers (Wicks, 1995; Machet, 2004), on university students and adults as well (Gallik, 1999; Kirsch \& Guthrie, 1984; Ali, 1994), and on certain cultures and society, such as Malaysian. For example, in one of the studies by Zin et al. (2014), many educators and employers described that Malaysian university study lack critical reading abilities because of their capacity to digest reading texts. According to the findings, students struggle to identify the primary idea, the purpose of the text, and key facts. Besides, Pandian (2000) discovered that over $80 \%$ of Malaysian university students are reluctant readers of both English and Malay materials. Therefore, reading skills are important to students' as it can influence their performance when they study and when they are working in the future.

Abdul Ghaffar and Abdul Aziz (2019) also claimed in their study that the ability and motivation of students to learn other English language abilities also might be affected by their reading skills. Hence, to highlight the importance of reading, teachers and school management also play a vital role in encouraging learners to read. In their study, Abdul Ghaffar and Abdul Aziz (2019) added that close collaboration between teachers and school management could help develop a positive and safe school and learning environment that encourages learners to learn more and acquire their reading skills for language learning. Moreover, reading is known as one of the important skills because the development of new words and the acquisition of vocabulary can be acquired through reading (Mohamad \& Abdul Aziz, 2020).

\section{Multimodal text as an Instructional Material}

According to Kress (2010), multimodality is a framework for establishing meaning that needs a group interpretation of two or more scripts, pictures, movies, graphics, animations, sounds, music, gestures, and facial expression. People nowadays generate meaning in various ways Thus, the traditional way of teaching and learning English should be broadened beyond the ability to read and write. It can be a great benefit to use multimodal texts as instructional material to learners. For example, Folker et al. (2005) mentioned in their study that they experiment with the multimodal material, which is a written text accompanying the graphic, and how it can help influence learners in learning. They found out that learners with a low proficiency level may gain significant benefits from using the multimodal material in the classroom.

Next, in her study, Istiqomah (2016) shared that her students' grades were gradually improved to $94 \%$ when using multimodal text as instructional material. She compared her students' outcomes between the group that uses the textbook as learning material and the group that uses multimodal learning. Every student agrees that multimodal teaching materials are useful and help students comprehend explanatory text. Students find the variety of explanation text presentation formats, such as written text, audio-visual (video), and an infographic, entertaining and helpful in understanding the sequence of events described in the explanation text for learning the English language.

There are many ways of teaching using multimodal text in ESL classrooms. One of the ways is using YouTube with a local YouTuber as the medium for language teaching and learning classroom. Wael (2016), in his study, shared that he wants to investigate the usefulness of the multimodal text contained in many YouTube videos for teaching English inside the classroom as instructional material and provides insight on a new way of teaching the English language. The findings found that YouTube with a local YouTuber may be quite useful in assisting learners in understanding their English classes, improving their performance, and expanding their knowledge of the language as they can relate to their real-life situations. Besides, Elyusra et al. (2019) also mentioned teaching multiliteracies using multimodal teaching in ESL classrooms. It brings positive feedback from learners as they are interested in learning a foreign language and feel motivated to participate in the class. Consequently, every 
student agrees that multimodal teaching materials are useful and help students comprehend explanatory text. Hence, the use of multimodal text as an instructional material gave benefits to the learners.

\section{Advantages of Using Multimodal Text as Improving Students' Reading Habit}

Teachers or educators are doing everything they can to improve learners' reading habits, for example, by implementing the multimodal text in the ESL classroom. The use of multimodal text can bring advantages to the learners as the text is the combination of two or more modes such as written language, spoken language, visual (still and moving image), audio, gestural, and spatial context. Besides, it can be an ideal alternative as a medium to aid language acquisition, particularly for reading comprehension. Hanif and Wiedarti (2021) use multimodal text, movies, to enhance their learners' reading skills. They mentioned that in order to keep students' knowledge up to date, English teachers should switch from traditional learning to modern learning using digital media. Teachers can maximize their learners reading skills using graphics. The findings also found that the advantages of using multimodal text as English learning materials can increase learners' motivation, provide new experiences, provide instructional content, provide cultural diversity information, improve comprehension skills, and ensure material authenticity (Hanif \& Wiedarti, 2021). This also can improve learners reading habits as they learn to read to subtitles when watching the movies.

Learners' are having difficulty in reading due to their poor reading habits. One way to address this issue is to provide them with a variety of reading opportunities. Cahayaningati \& Lestari (2018) shared that the use of multimodal text can improve their students' reading skills. Their learners' positive feedback also supports the findings. They shared that by using multimodal text in learning English, they can improve their reading skills and their motivation to learn a foreign language. They were interested in learning English since the multimodal text is able to deliver the message in a variety of ways, including visual, audio, and motion. Furthermore, learners were given the opportunity to grasp texts reinforced by visual pictures and sounds by reading multimodal text on the internet. When a text is provided in two channels, visual and audio, learners can absorb it better (Mayer, 2005).

Moreover, learners can gain advantages by using multimodal text as well as improving their reading habits as learners in the 21 st century are exposed to multimodal text. For example, Yusof et al. (2017), in their study entitled "Teacher Trainees' Perspectives of Teaching Graphic Novels to ESL Primary Schoolers", shared that teachers should be prepared to use multimodal text for language teaching. Based on the findings, learners are eager to learn and read English using graphic novels. Moreover, Thompson and McIlnay (2019) also agreed that in an ESL classroom, the use of multimodal text had been demonstrated to have positive feedbacks such as boosting learners' participants, improving learners reading habits, motivating learners, helping learners appreciating more on their own culture and building learners confidence. Educators and schools need to come out with new and creative ways to encourage learners to read, and by using multimodal text is one way to encourage learners to keep on reading and learning the English language.

\section{Discussion}

Stakeholders such as parents, teachers, and school administrators need to bear in mind that the educational aim of students is to instil enthusiasm for both reading and lifelong learning. Therefore, based on the literature review above, there is better insight into understanding reading habits, the importance of reading, multimodal text as instructional material, and the advantages of using multimodal text to improve reading habits. It can guide these stakeholders to inculcate, establish and strengthen student love for reading as reading is one of the keys to both school and life success.

Fardon (2013) viewed learning style as a stable preference that is used by individuals to effectively organise, process and develop their understanding of any learning challenge, task or situation. According to the previous study, it was proven the use of multimodal text might improve students reading habits (Mathew \& Alidmat, 2013; Oriogu, 2015; Yunus et al., 2013). Hence, by using multimodal text for language learning, it may encourage students not only to learn by listening and 
responding to what the teachers have said, told and given in the classroom but to take their own initiative in reading what they are learning to develop their own understanding of the lesson.

\section{Conclusion}

As mentioned earlier, this conceptual paper provides a literature review on the reading habit, importance of reading, multimodal text as instructional material, and the advantages of using multimodal text as improving reading habits. The advantages of multimodal text in improving students' reading habits cannot be ignored. Thus, it is necessary for teachers, educators and school management to consider using multimodal text in language learning class which may lead to improvement of students' reading habits. However, there are many factors that may not be considered important when it comes to students' reading habits. Thus, through this conceptual paper, the researcher tried to highlight some important factors that may increase students' habit of reading. The existing literature has identified few advantages in using multimodal text, such as making the learning more interesting and productive, encouraging more on reading habits and motivate students to read texts with passion. Therefore, it is necessary for educators to be aware of their learners' difficulties when reading and how to improve learners' reading habits.

It is advisable for teachers to avoid using the same method while teaching in a language learning classroom. Hence, teachers can introduce multimodal text to students and explained the benefits that they get when using it. Teachers can give the opportunity for learners to choose what kind of multimodal text they want to use in order to increase their reading habits. This opportunity will expose learners to how to use various multimodal texts and experience the differences of each aids when they use it in teaching and learning. Learners also can appreciate more on their own culture when using the multimodal text prepared by teachers when teaching and learning the English language.

\section{References}

Abdul Aziz, A., Narayanasamy, J., Mohamad, M., Md Yunus, M., \& Hameed, H. (2019). StudentTeachers' Experiences in Developing Oral History Texts for the Teaching of Reading in the Form Two ESL Classroom. 3Rd International Conference On Social Science, Humanities And Technology.

Abdul Ghaffar, M., \& Abdul Aziz, A. (2019). The problems in reading skills of English among rural primary school pupils. Religación, 4, 81-86.

Ali, A. (1994). Reading interest among MIT students with special reference to Islamic literature. unpublished manuscript.

Bashir, I.\& Mattoo, N. H. (2012). A Study on Study Habits and Academic Performance Among Adolescents (14-19) years. International Journal of Social Science Tomorrow, 1(5), 1-5.

Cahyaningati, D. T., \& Lestari, L. A. (2018). The Use of Multimodal Text in Enhancing Engineering Students' Reading Skill. International Journal of Language Education, 2(2), 65-73.

Fardon, M. (2013). Relationships between students' learning style preference and exam achievement in differing forms of assessment during an advanced apprenticeship at a vocational Further Education College. Institute of Learning, Department of Education, University of Oxford. Retrieved from.

Folker, S., Ritter, H., \& Sichelschmidt, L. (2005). Processing and integrating multimodal materialthe influence of color-coding. In Proceedings of the annual meeting of the Cognitive Science Society, 27.

Gallik, J. D. (1999). Do they read for pleasure? Recreational reading habits of college students. Journal of Adolescent \& Adult Literacy, 42(6), 480-488.

Hanif, N., \& Wiedarti, P. (2021). The Use of Movies as Reading Comprehension Materials for Eighth Grade. International Journal of Linguistics, Literature and Translation, 4(4), 178-184.

Istiqomah, S. P. (2016). The development of learning material: Explanation text based on multimodal by using Sway app in 11th grade of SMAN 1 Batu. International Journal of Education and Research, 4(9), 313-322. 
Johar, N., \& Abdul Aziz, A. (2019). Teachers' Perceptions on Using the Pulse 2 textbook. Journal Of Educational Research \& Indigenous Studies, 2(1).

Khairuddin, Z. (2013). A Study of Students' Reading Interests in a Second Language. International Education Studies, 6(11), 160-170.

Kirsch, I. S., \& Guthrie, J. T. (1984). Adult reading practices for work and leisure. Adult education quarterly, 34(4), 213-232.

Krashen, S. (1993). The power of reading. Englewood, CO: Libraries Unlimited.

Kress, G. (2010). Multimodality: A social semiotic approach to contemporary communication. Routledge.

Kubota, R., \& Mckay, S. (2009). Globalization and Language Learning in Rural Japan: The Role of English in the Local Linguistic Ecology. TESOL Quarterly, 43(4), 593-619.

Machet, M. P. (2004). Reading and Use of Informational Material by South African Youth. School libraries worldwide, 10.

Maharsi, I., Ghali, M. I., \& Maulani, S. (2019). High school students' reading habit and perception on reading for pleasure. International Journal of Indonesian Education and Teaching, 3(1), 80-89.

Mayer, R. E. (2005). Cognitive theory of multimedia learning. The Cambridge handbook of multimedia learning, 41, 31-48.

Ministry of Education. (2013). Malaysia Education Blueprint 2013 - 2025. Putrajaya.

Palani, K. K. (2012) Promising Reading Habits and Creating Literate Social. International Reference Research Journal, 2(1), 91.

Pandian, A. (2000). A study on readership behaviour among multi-ethnic, multi-lingual Malaysian students. In 8th International Literacy and Educational Research Network (LERN) Conference on Learning, RMIT University, Melbourne, July (pp. 5-9).

Priajana, N. (2013). Student teachers' reading habits and preferences. Journal on English as a Foreign Language, 3(2), 71-76.

Serafini, F. (2011). Expanding perspectives for comprehending visual images in multimodal texts. Journal of adolescent \& adult literacy, 54(5), 342-350.

Thompson, R., \& McIlnay, M. (2019). Nobody wants to read anymore! Using a multimodal approach to make literature engaging. Journal of English Language and Literature, 7, 21-40.

Wicks, J. (1995). Patterns of reading among teenage boys: The reading habits and book preferences of 13-15-year-old boys. New Library World.

Yunus, M. M., Salehi, H., \& John, D. S. A. (2013). Using visual aids as a motivational tool in enhancing students interest in reading literary texts. arXiv preprint arXiv:1305.6360.

Yusof, S. M., Lazim, Z. M., \& Salehuddin, K. (2017). Teacher Trainees' Perspectives of Teaching Graphic Novels to ESL Primary Schoolers. 3L: Language, Linguistics, Literature ${ }^{\circledR}, 23(3)$.

Zin, Z. M., Wong, B. E., \& Rafik-Galea, S. (2014). Critical reading ability and its relation to L2 proficiency of Malaysian ESL learners. 3L: Language, Linguistics, Literature ${ }^{\circledR}, 20(2)$. 